\title{
Contracting school meals in a rural Florida district
}

Contracting school meals

\author{
Mark Traynor \\ School of Hospitality and Tourism Management, \\ Florida International University Biscayne Bay Campus, North Miami, \\ Florida, USA \\ Can Chen \\ Department of Public Policy and Administration, \\ Florida International University, Miami, Florida, USA, and \\ Miranda Kitterlin \\ School of Hospitality and Tourism Management, \\ Florida International University Biscayne Bay Campus, North Miami, \\ Florida, USA
}

\begin{abstract}
Purpose - The purpose of this paper is to examine the decision to contract school meal services and the associated nutritional and financial impacts on school districts. Given the increase in the use of competitive contracting of public school meal services and the critical role that school meal services play in public health, this is an important subject to investigate.

Design/methodology/approach - A case study was performed using one US school district with privatized food service. Face-to-face interviews were conducted with school food service decision makers. Other data collection included the analysis of public documents such as the school district's budgets and financial statement reports (the cost per lunch and breakfast meals, the cost for labor, contract, transport, supplies and food expenses) and school food service policies (contract policies). Supplementary data pertaining to district social-demographic profiles and full-time equivalent enrollment figures were also collected from state departments.

Findings - Analysis of interviews revealed that positive financial motivations and impacts were dominant factors related to contracting food services in the district. A significant finding was the relatively short turnaround in the district's negative financial situation as a result of contracting out the food services. These findings provide valuable insight and support for rural school districts in similar negative financial situations seeking to contract out food services.

Originality/value - Many studies have examined contracting out of technical services, such as transport and waste management, and social services, such as correctional services and health; however, there is a lack of studies documenting the effects of contracting out of school meal services.
\end{abstract}

Keywords Public school privatization, Contracting out, Privatization, School food services

Paper type Research paper

\section{Introduction}

Privatization covers a wide set of arrangements where private sector organizations contract with public sector bodies for the delivery of services using public funds (Petersen and Hjelmar, 2013). One of the most common forms of privatization is competitive contracting, also known as contracting out. This approach entails the private provision of publicly funded services where the public sector retains the overall financial responsibility (Bhatti et al., 2009). Contracting out constitutes an increasingly utilized alternative to the public provision of services in industrialized

(C) Mark Traynor, Can Chen and Miranda Kitterlin. Published in International Hospitality Review. Published by Emerald Publishing Limited. This article is published under the Creative Commons Attribution (CC BY 4.0) licence. Anyone may reproduce, distribute, translate and create derivative works of this article (for both commercial and non-commercial purposes), subject to full attribution to the original publication and authors. The full terms of this licence may be seen at http://creative commons.org/licences/by/4.0/legalcode
Received 15 November 2018 Revised 28 January 2019 Accepted 9 March 2019 
IHR

33,2

countries throughout the world (Ohlsson, 2003; Stolt et al., 2011; Rostgaard and Szebehely, 2012). The USA is no different; government agencies across all levels (federal, state and local) have migrated from direct public service provision to competitive contracting. Many important technical (waste management and transport) and social public services (public health) experience a significant level of contracting out (Savas, 2005).

There is a long history of privatization of non-instructional services in education in the USA (Burch, 2006). For instance, in 2017 it was found that 71.5 percent of school districts in the state of Michigan contracted out at least one of the three major non-instructional services, custodial, food services and transportation (Hohman and Cammenga, 2017). There is an increase of 40 percent from 2001 (Hohman and Woodman, 2015).

Regarding school food services, most school districts participate in federally assisted child nutrition programs such as the National School Breakfast Program (NSBP), the National School Lunch Program (NSLP) and Special Milk Program for Children (US Department of Agriculture, 2008). These programs are run by the Food and Nutrition Service of the US Department of Agriculture (USDA). In total, 32m children participate in the federal school meal programs every school day (US Department of Agriculture, 2015a). In order to receive reimbursement for schools under these federal programs, they must align with the Healthy, Hunger-Free Kids Act of 2010 by meeting the nutritional standards and requirements detailed in the Nutrition Standards for Foods in Schools report, published by the USDA in 2007, in consultation with Institute of Medicine (US Department of Agriculture, 2013).

These government-funded programs can make up a huge portion of the food service budget of a district, and thus present both challenges and incentives for school districts to provide quality and efficiency in their food services. A study conducted by the USDA in 2008 to examine the cost of producing reimbursable school meals found that, on average, the production of a fully reimbursable lunch exceeded the federal subsidy by $\$ 0.60$ (US Department of Agriculture, 2008). Furthermore, a survey conducted by the School Nutrition Association examining the impact of the federal nutrition regulations, introduced in 2012, found that nearly 80 percent of school districts had to take measures to offset food service financial losses through various measures such as reducing staffing, using meal program reserve funds, limiting menu choice, and deferring equipment investments (School Nutrition Association, 2015).

It has been suggested that school districts could be leaving millions of dollars on the table by not pursuing privatization of their food service operations (Hohman and Kollmeyer, 2011). School food service programs in Florida's schools provide approximately six percent of the school lunches served in the USA, generating over half a billion dollars (US Department of Agriculture, 2015b). According to Florida School Food Nutrition Association (2015), school food service operations through NCLP and NSBP provided 681,817 school breakfasts and 1,442,209 school lunches, respectively, and served daily during the 2013-2014 fiscal year. The most recent available report indicates that out of 67 county school districts in Florida, six districts have elected to privatize their school food service operations (LaFaive, 2007).

The decision to contract out public services can be influenced by a number of motivations including financial, administrative (managerial) and/or political factors. It has been used as a managerial strategy for achieving efficiency and flexibility of programs (Rho, 2013). In many instances, contracting out is a direct response to increasing pressure put on government agencies to do more with less. This may be due to budgetary restraints of state and districts, or even the emergence of public management reforms (Nicholson-Crotty, 2004). The significant cost savings associated with contracting are seemingly a result of the incentives introduced by competition for tender of contracts (Alonso et al., 2015). However, some scholars have argued that the initial financial and efficiency effects of contracting are limited and tend to decrease over time (Bel et al., 2010; Hodge, 2000; Bekken et al., 2006; Boyne, 1998; Houlberg and Petersen, 2015). Thus, measuring the effects of contracting out is an imperative and necessary task that involves assessing the service quality and the economic impact. 
Many studies have examined contracting out of technical services, such as transport and waste management, and social services, such as correctional services and health; however, there is a lack of studies documenting the effects of contracting out of school meal services. Given the increase in the use of competitive contracting of public school meal services, and the critical role that school meal services have in public health, this is an important subject to investigate. Thus, the purpose of this study was to examine the decision to contract school meal services and the associated nutritional and financial impacts on school districts. A single case study approach was taken; a rural school district in Florida, USA, which participated in the NSLP, was selected as the setting. Furthermore, this public school district had an established history of contracting out school meal services. It had privatized food service for 20 years and was a leader in privatization efforts among Florida school systems.

The central research questions of this study are as follows:

$R Q 1$. What were the motivations for a rural school district to contract out the school food services?

$R Q 2$. What were the major impacts of contracting out school food services for school districts, such as the financial, nutritional and student academic performance?

The results can provide a valuable insight and an improvement in our understanding of the nutritional impact of privatized school food service operations on the ability of school districts to meet state and federal nutritional requirements, Kindergarten to Grade 12, as well as the financial impact on the school districts' operating budgets. One major potential significant outcome of this work is policy reform in relation to school meals and the privatization of school food services.

\section{Literature review}

Privatization is a topic that concerns many scholars, government practitioners, and citizens. There is a voluminous literature on this subject. In general, privatization research can be categorized into two lines of inquiry. One line of research empirically investigates the motivations and determinants of privatization decisions in different kinds of public services (Curry, 2010; Ferris, 1986; Levine, 2010; LaFaive, 2007). A second line of research examines the effects of privatization on public service delivery (Levin and McEwan, 2002; McGuire and Van Cott, 1984; Brooks, 1995).

\section{The determinants and effects of contracting out services in the government sector}

Generally, the literature has found that contracting is done primarily to save money and improve the quality of public services (Curry, 2010; Levine, 2010; LaFaive, 2007). Curry (2010) finds that the declined public revenues and the need to efficiently and effectively deliver public services are the major driving forces for municipal general administration services, emergency responses, and financial performance evaluation and audit services. Both LaFaive (2007) and Levine (2010) contend that cost savings and improving the quality of food services are the main reasons for many school districts to contract out school food services.

Researchers have also identified several specific factors influencing public agencies' utilization of privatization for the implementation of programs and services. For example, Ferris (1986) examines the determinants of privatization decisions in U.S. municipalities. He found that large and urban cities are more likely to privatize than small and rural cities. In addition, cities are less likely to privatize when they have a strong labor union and sound fiscal health. Brooks (1995) examine why some cities contract out solid waste collection, whereas others maintain internal operations. They find that municipalities are more likely to turn to privatization when the local tax burden increases, multiple alternative service producers exist, and citizen's demand for service increases. Hart et al. (1997) and 
IHR

33,2

Boyne (1998) find that public agencies are moving away from internal operation and favoring privatization due to a growing sentiment that government is too large, less efficient, and untrustworthy. There are several theoretical arguments regarding the effects of contracting in the public sector that have been put forward and tested by scholars. Theoretical claims of the potential positive effects commonly come from public choice (competition) and property rights (ownership) theories (Domberger and Jensen, 1997; BlomHansen, 2003; Alonso et al., 2015). In theory, privatization of government services is assumed to achieve cost savings because of competitive pressures and economies of scale in the private production process. It has been argued that this competition forces private sector organizations to optimize their efficiency, whereas, in contrast, public organizations continue to perform at sub-optimal levels without the risk of going out of business (Alonso et al., 2015). In addition, the incentive structure in the private sector is more conducive to efficient production than its counterpart in the public bureaucracy (Spann, 1977). However, studies have found mixed evidence on cost savings. On the positive side, Savas (1977) and Brooks (1995) find that in the case of municipal solid waste service, contracted private sector collection is less costly than public sector collection when the population exceeds 50,000. Similarly, in the area of school bus transportation service, McGuire and Van Cott (1984) assert that substantial savings could result from privatizing. In one of the few empirical studies of school food service contracting, Hohman and Kollmeyer (2011) found that officials reported saving an average of $\$ 34$ per pupil on food service contracts.

However, many studies also documented negative cost effects of contracting. Harding (1990) and Alspaugh (1996) found that in-house provision is more efficient than the private operation of school bus transportation. Callan and Thomas (2001) found that there was no difference between public and private production of municipal solid waste service in Massachusetts. Recently, Bel et al. (2010) conducted a meta-regression analysis of 27 econometric studies examining privatization of water distribution and found no systematic support for lower costs with private production in municipal solid waste and water services. The US Government Accountability Office (2011) contends that an estimated $\$ 860 \mathrm{~m}$ (8.6 percent) in school year 2005-2006 was paid improperly to food service contractors because of errors in the number of meals provided. The scholars also emphasize that the role of competition is critical for cost savings; if there is little competition among private vendors, there is little incentive for companies to provide low-cost bids (Savas, 2000; Kassel, 2010; Curry, 2010).

Apart from the purported cost effects, the literature on school food services in public school districts is very limited. It is primarily based on normative criticisms of privatization including lack of public accountability and transparency, dependency, restricted flexibility, a loss of control, and a lower quality (LeBruto and Farsad, 1993; Levin and McEwan, 2002; Mathis and Jimerson, 2008; Nestle, 2002; VanderSchee, 2005). Beyond this speculation, we know little about the actual experiences and results of contracting school food services. Petersen et al. (2018) published a comprehensive review of international empirical studies over a 14-year period on the economic and quality effects of contracting public services to the private sector. They concluded that due to a lack a significant studies that include measures of transaction costs, it is challenging to evaluate the impact of competitive contracting on overall cost effectiveness. They also added that generalizing the effects from contracting out should be made with caution and are likely dependent, among other things, on the transaction costs' characteristics of the service, the market situation and the institutional/regulatory setting.

Contracting out food services in universities and colleges

Due to the reduced public funding coupled with increased demands for financial accountability, outsourcing has become widely accepted by both public and private universities. The National Association of College and University Food Services contend that as of June 1997, 139 of its 580 
institutional members had contracted out school food services (King, 1997). These privatized universities believe that corporate partners are assumed to be more capable of handling food service operation economically and efficiently and they are not legally required to follow the complicated and time-consuming bid-and-approval processes that a state public institution must go through in order to set up operations (King, 1997). With more students on campus 24-hours a day for 7 days a week, college students today demand more food service options than ever before (Lawn, 2003). By outsourcing food service operations, universities can concentrate on retaining a satisfied student population without concerning the food service factor. Contracting with a reliable business company can meet the needs of the students by providing broader food and payment options and accommodating students who prefer late night choices (King, 1997). McConnell (1999) conducted a survey of 861 members of the National Association of College Auxiliary Service and concluded that the personal characteristics of university administrators are correlated with the outcomes of the decision on outsourcing and in-house operation. A new university administrator, specifically a female, will tend to restructure campus food services and will decide to build a partnership with private companies in the delivery of school food services.

Although there are potential benefits of contracting out food services, studies have pointed out that there are many challenges resulting from privatization of food services. Hutchcraft and Hume (2000) argue that the higher turnover rate, the low wage, and the stronger labor union in the food service industry often cause contract negotiations between universities and corporate partners, leading to unstable operation of school food services. Gupta et al. (2005) find that about one in five universities is outsourcing campus dining services. They also conclude that the greatest concerns regarding food service outsourcing are increases in the cost of the food service, a loss of control and inability to manage the contracting business partner, and a decline in the quality of food service. In a subsequent study, Glickman et al. (2007) use a detailed case study including interviews with university administrators, contractor administrators, and students to offer an in-depth examination of the outsourcing of food service on a university campus (Georgia Washington University). Their findings reveal a series of challenges and issues for the university and the corporate partners providing the outsourced food services. On the one hand, universities need to ensure the delivery of high-quality of food services and consider the student population and their relationship with the contracted employees. On the other hand, the business partners shall cope with varying issues in the operation of university food services such as local competition, labor availability, and serviceability, and low margins of profits.

\section{Methodology}

A case study was performed using one Florida school district with privatized food service. This public school district was selected because it was a leader in privatization efforts among Florida school systems, having privatized food service for more than 20 years. The school district consisted of 2,582 employees and 91 administrators countywide at the time survey took place (2017). In total, the district included 17 elementary, 8 middle, 7 high schools and 1 pre-kindergarten center.

\section{Sample}

Face-to-face interviews were conducted with school food service decision makers. A sample of 5 participants, with varying lengths of service in the respective position from the school district, was targeted by contacting the school district administration. The sample consisted of: Superintendent (8 years' service), Director of Purchasing and Contract Administration (31 years' service), Director of Nutrition (11 years' service); Dietitian and Operations Manager (4 years' service), and School Board Members. All, except one, members completed the interview. The School Board Members were unavailable at the time of the interview, so they were not included in the sample.
Contracting school meals 
IHR

33,2

\section{Data collection}

Data were collected by two members of the research team who traveled to county locations to conduct the field interviews. Participation was voluntary and confidential, and involved the completion of a 60-minute in-depth interview. Two trained researchers conducted all interviews to ensure consistency in questioning and probing. Interview questions centered on the focus of the study - the financial and nutritional impacts of school food service privatization (see the Appendix). Prior to conducting interviews, a pilot test of the interview script was conducted with an individual holding a comparable food service decision-making position in another Florida country school district.

Other data collection included the analysis of public documents such as the school district's budgets and financial statement reports (the cost per lunch and breakfast meals, the cost for labor, contract, transport, supplies, and food expenses) and school food service policies (contract policies). Supplementary data pertaining to district social-demographic profiles and full-time equivalent (FTE) enrollment figures were also collected from the Florida Department of Education, the Florida Department of Agriculture and Consumer Services, the US Census of Bureau, and the US Department of Health and Human Services.

\section{Analysis}

Each interview was audio-recorded and was then transcribed verbatim, and each member of the research team (three in total), including the interviewer, independently read, analyzed, and coded the data using the inductive thematic analysis; this independent coding was performed to strengthen reliability (Braun and Clarke, 2006; Creswell, 2007). First, each member read the interview transcripts in entirety to establish familiarity with the data. Then, segments of the text were labeled with codes that described their content or meaning. Next, three researchers compared their independently derived codes and came to an agreement on broad themes into which each of the codes could be collapsed; common themes were identified and overlapping codes were combined into themes using agreement between each of the members of the research team. Themes were not finalized until 100 percent agreement was reached by the research team members.

\section{Results}

Motivations for contracting out school district food services

The findings from the field interviews are described according to the common themes and subthemes that emerged from analysis. The themes and subthemes related to the motivational factors to contract out the district food services to a large private food service management company are summarized in Table I.

\section{Theme 1: financial motivations to contract out}

The first emergent theme from the analysis of responses was financial motivations to contract out the food services in the district (Table I). Subsequently, two associated subthemes emerged from the analysis. The first subtheme was the district food service department operating in a financial deficit prior to contracting out. A number of participants explained that the school district was operating in a financial deficit prior to contracting out the food services, "the previous food service director was not successful financially," and "the school district was in the red [financial deficit]. That was the first reason to privatization." The second subtheme that emerged from the data was the supplementation of the food service operating fund account by the general fund account. A participant stated that prior to contracting out the school food services, "the school board had to take money they would spend on students to supplement the school food services." 
Theme 2: other contracted school district services

An important theme that emerged from the data analysis was the contracting out of other school services within the district, which subsequently served as a model for successful implementation. Participants indicated that this was a major motivation to contract out the school food services. A central subtheme of this theme was a successful contracting out of other school services in the district prior to the food services, thereby serving as a model. It was explained that the custodial and transport services were contracted out to private firms for a number of years prior to the decision to contract out the food services; "the first contracted services were custodial services, followed by school transport."

Theme 3: the relinquishment of responsibilities for day-to-day food service operations while retaining ultimate control of food service operations

The relinquishment of the responsibilities for the day-to-day food service operations by the school district administration was another emergent theme. Several subthemes related to this theme emerged from the data analysis (Table I). The foremost subtheme was the burden of the school district administration to manage the food service operations for the district. It was explained that the school district administration was responsible for all aspects of the food service operations prior to contracting out the food services, from financial liabilities and human resources (hiring and payroll, etc.) to procurement and preparation of food products. Respondents cited that "the school Principal does not have to worry about whether we have enough cooks. That is the responsibility of the food service contractors. By hiring a company to do this, that greatly relieve our jobs and responsibility." "It [contracting out] removed some liabilities that the school district had. It removed some cost-related retirements that the school board would have to pay. It gives us a great flexibility in finance."

\section{Impacts of contracting out school district food services}

A summary of themes and subthemes related to the impacts of contracting out the school district food services to a large private food service management company is summarized in Table II.

Theme 1: overall positive financial impact allowing for funds to be reallocated to other areas The first major theme that emerged from the analysis of responses was the overall positive financial impact of contracting out the school food services in the district. The most frequently described subtheme was the relatively short turnaround in the school district's financial situation, resulting from the contracting out of the school food services. A few participants made note that general fund balance was impacted directly by the improvements in fund

\begin{tabular}{ll} 
Themes & Subthemes \\
\hline Financial motivations to contract out & $\begin{array}{l}\text { School district food service department operating in a } \\
\text { financial deficit prior to contracting out } \\
\text { Supplementation of the food service operating fund account } \\
\text { by the district general fund account }\end{array}$ \\
$\begin{array}{l}\text { Successful contracting out of other school district services } \\
\text { Other contracted school district services, } \\
\text { thereby serving as a model }\end{array}$ & $\begin{array}{l}\text { Support and commitment from the school district } \\
\text { administration }\end{array}$ \\
$\begin{array}{ll}\text { The relinquishment of responsibilities for day } \\
\text { Bu-day food service operations while retaining } \\
\text { school food services } \\
\text { ultimate control of food service operations }\end{array}$ & $\begin{array}{l}\text { Subject matter expertise and resources of the private food } \\
\text { service management company } \\
\text { Retention of control of food services by the school district } \\
\text { administration }\end{array}$
\end{tabular}

Contracting school meals 
IHR

33,2

\section{0}

Positive impact on ability to meet federal

nutritional regulations

Table II.

Summary of themes and subthemes related to the impact of contracting out school district food services to a large private food service management company funds to be reallocated to other areas schools within the school district

service operations

Gradual acceptance of implementation of by all stakeholders

\section{Subthemes}

Overall positive financial impact allowing for

Relatively short turnaround financial situation Transfer of financial responsibility to the private food service company

Expertise, economies of scale and bargaining power of private food service management company

Expertise and resources of the private food service management company allows for efficiency in operations and meeting of frequently changing guidelines requirements of federal school meal programs

School district should focus on the core function of education

Positive impact on students that are enrolled in Nutrition education programs for students on healthy eating

and food choices

Exposure to a wide variety of foods to increase students' interest in healthier foods

Positive impact on student behavior and cognitive ability, especially for low-income and at-risk populations

Development of positive clean and modernized dining environments

Nutritious meal for low-income, at-risk student population

Overall impact of contracting out to the private School district retains the ultimate control of food service food service management company on the food operations private management of district food services

School district being pleased with the management of the food services

Initial concerns regarding job security, etc

Successful contracting out of other school district services as models helped to ease job security concerns

Higher turnover of food service staff

Requirement of total support from main stakeholders

balance of the food service. When participants spoke of this, they referred to school district general fund balance, which was used to supplement food service funds. An example of a response tied to this subtheme included, "the district was in a red [financial deficit] and was having to supplement the school food services budget. So, when we contracted it out, it took about three years for them [private foodservice company] to get us in a positive fund balance. Since then, we stay in the black [positive finances]. The fund balance growth in the school food service was exponential." A significant contribution to this growth in the general fund balance was attributed to the district being "reimbursed [by the USDA] a little bit more than what is paid to the contractor." Ultimately, this allowed for funds to be reallocated to other areas.

Another important subtheme related to this theme was the transfer of financial liability for administration and human resource (HR) related duties from the district to the private food service management company. Participants cited that "we [private foodservice company] actually take all the administration cost away from the administration. Our goal is to take away all the administration cost and all the personnel cost. That financial burden actually is taken away from the district." This considerable reduction in HR expense was mainly attributed to the school district for not having to "pay the cost of retirement."

\section{Theme 2: positive impact on ability to meet USDA federal school meal guidelines and standards}

A second prominent theme was the positive impact of contracting out the district's school food services on the ability of the school district to meet federal nutritional standards and regulations. A frequent subtheme that occurred was the presence of expertise and resources of 
the national food service company, which did not previously exist within the school district, allowing for efficiency in operations and meeting of frequently changing nutritional requirements. This has a major financial implication, in that, the school district is reimbursed by the USDA for each meal that meets the nutritional regulations. Examples of some responses that provide insight into this subtheme included that the contractor is "highly motivated to make a profit and therefore meet nutritional regulations, if they don't meet [these] requirements they don't get paid (reimbursed)." Furthermore, it was also noted that the contractor has the "nutritional expertise to help meet federal nutrition standards." Another response related to the expertise and resources of the contractors was their "ability to conduct research to find out what the students want to eat." An example provided by a participant was finding the best tasting burger that the children were willing to eat and that also met the USDA nutritional regulations. It has been shown that significant changes in the standards related to nutritional quality of school meals in 2012-13, imposed by the Healthy Hunger-Free Kids Act of 2010, have contributed to increases in food waste and costs related to food waste (Byker Shanks et al., 2017).

\section{Theme 3: positive impact on students that are enrolled in schools within the school district} The positive impact on school district students was another theme found in the analysis. There were several subthemes that emerged within this theme itself. Providing nutrition education for school district students regarding healthy eating and food choices was a major subtheme that was discovered. Some responses related to this subtheme included, "they [the contractor] offer days of education on food, I think they [the school kids] are eating healthier food because that is what is being offered." Another educational programs that was mentioned was recipe competitions in the elementary school, "students actually create the recipe, name the recipe, and they compete [with each other]." Participants cited that the steady growth in revenue, resulting in a stable and healthy reserve fund, freed up finances to invest on student's welfare. Examples of statements included, "we know that in a well-nourished and fresh and clean cafeteria environment child academically will do better," "students are dining in clean and modern facilities," and "refurbishment of catering services in 19 schools in the district."

\section{Theme 4: overall impact of contracting out on food service operations}

The overall impact of contracting out food service operations was another theme that emerged from the analysis. The first prominent subtheme related to this theme was the retention of the ultimate control of the food service operations by the school district administration. Another important statement related to this subtheme was centered on the contract being a fixed-term contract, "the 5-year cycle for contract negotiations ensures that school district retains control over services as the contracting process is a highly competitive process." It was also explained that the contractor wants "to understand what they [school district] need. In order to understand what is going on in the district, we [food service company staff] attend the board meeting, faculty meeting, and administration conference."

Another subtheme was the school district being pleased with the overall management of the food services. Some statements linked with this subtheme included: "we [the school district] are very happy with the contractor, I do think the quality of meals improved and our school participation [in federal school meal programs] rate has been up." It appeared that due to the presence of expertise and resources of the private food service company, the overall meal operations at each school is run more efficiently: "we [private foodservice company] have an operational manager in the schools every day to supervise. That was not available before the contracting out." The fact that the contract is a "performance-based contract" appears to have motivated the private food service company to reduce costs while
Contracting school meals 
IHR

33,2

82

still providing a quality service and product. Related statements from participants included: "we [the school district] pay fixed-fee per meal. If the contractor does not sell a lunch, they do not get paid" and "failure to comply with federal standards will disallow all the meals served and we [the school district] won't get the federal reimbursement."

\section{Theme 5: gradual acceptance of implementation of private management of district food} services by all stakeholders

Several participants discussed the gradual acceptance over a period of time of implementation of private management of district food services by all stakeholders. This theme was seen in both the participants' school district and private food service company staff. Numerous participants indicated that there were initial concerns regarding job security; this manifested itself in the form of a "negative mindset toward privatization, a fear of losing jobs." It was explained that there was an "initial perception that they [contractor] are taking local jobs away and also do not look after the people [staff] the same way the school district did." A major factor in easing the concerns over job security was the contracting out of other school district services prior to the food services, thereby serving as a model: "first contracted services was custodial services, followed by school transport, successful implementation of eased concerns." An apparent negative impact of contracting out was the apparent "higher turnover of foodservice staff." This may be due to differences in fringe benefits associated with being employed directly by the school district and by a private food service management company.

\section{Document analysis}

State and school district demographic profile and enrollment data

Population and FTE enrollment, including growth rate percentage, for state and school district population from 1990 to 2017 are presented in Table III. Overall, the district has experienced an aggregated population growth of 113.6 percent over the period of 1990-2017. In particular, between 1990 and 2000, the district experienced a considerable growth in population of 44.3 percent. In fact, this was nearly double the growth rate for the state of Florida (23.5 percent). The population growth rates appear to decline between 2000 and 2010 (28.6 percent), and between 2010 and 2017 (15.1 percent) (US Census Bureau, 2018; Florida Legislator, 2017).

A similar trend in growth rates of FTE for the state and school district over this period (1990-2017) can be seen. In total, the district experienced an increase of 37.1 percent in FTE. This increase can be attributed to an increase in population of the district and the state over the same period. As expected, the period between 1990 and 2000 experienced the greatest increase in FTE enrollment, at 43.8 percent for the district and 30.5 percent for the state.

Table III.

Data for district and Florida state population and percentage $(\%)$ of growth from 1990 to 2017

\begin{tabular}{|c|c|c|c|c|c|c|c|c|}
\hline Year & $\begin{array}{c}\text { District } \\
\text { population }\end{array}$ & $\begin{array}{l}\text { District } \\
\text { population } \\
\% \text { growth }\end{array}$ & $\begin{array}{c}\text { State } \\
\text { population }\end{array}$ & $\begin{array}{l}\text { State } \\
\text { population } \\
\% \text { growth }\end{array}$ & $\begin{array}{l}\text { District } \\
\text { FTE }^{\mathrm{a}}\end{array}$ & $\begin{array}{c}\text { District } \\
\text { FTE }^{\mathrm{a}} \% \\
\text { increase }\end{array}$ & $\begin{array}{l}\text { State } \\
\text { FTE }^{a}\end{array}$ & $\begin{array}{l}\text { State } \\
\text { FTE }^{\mathrm{a}} \% \\
\text { growth }\end{array}$ \\
\hline & & 0.0 & $12,938,071$ & 0.0 & 15741 & 0 & 592 & 0.0 \\
\hline 00 & 7,743 & 44.3 & $15,982,824$ & 23. & & 43.8 & $2,430,128$ & 30.5 \\
\hline 2010 & 151,372 & 28.6 & $18,801,310$ & 17.6 & 25,064 & 10.7 & $2,629,327$ & 8.2 \\
\hline 2017 & 174,272 & 15.1 & 20,984 & 11 & 27,995 & 11.7 & $2,804,865$ & 6.7 \\
\hline Total Increase ${ }^{b}$ & 92,664 & 113.5 & $8,046,329$ & 62.2 & 5,362 & 77.8 & 943,273 & 50.7 \\
\hline
\end{tabular}

Notes: ${ }^{\mathrm{a} F T E}$ is full-time equivalent enrollment; ${ }^{\mathrm{b}}$ total increase for the period of 1990-2017

Sources: US Census Bureau (2018) and Florida Legislator (2017) 
During this period, an average increase of 3.7 percent in FTE per academic year was experienced, with the greatest increase being experienced in the time leading up to contracting out (before 1990 to 1997).

\section{Financial statement analysis}

Audited annual financial statements for this school district from 2000-2001 to 2017-2018 were collected. There are no financial statements available for years prior to 2000. Figure 1 shows the historical trend of fund balance in this district's food service fund after contracting out the school food services. While no financial reports were obtained for the period prior to contracting out (before 1997), it can be seen that the food service fund balance for the 2000-2001 was considerably low at $\$ 185$. This clearly indicates that the fund balance of school food service has increased from $\$ 185$ in 2000-2001 to $\$ 5,340,763$ in 2017-2018.

Besides reviewing the fund balance data of school food service fund, the total revenue for the school district's food service fund was also analyzed. Figure 2 shows that the total revenue for school food services has increased dramatically from $\$ 6.5 \mathrm{~m}$ in $2000-2001$ to over $\$ 12 \mathrm{~m}$ in $2017-2018$.

\section{Conclusion and discussion}

The performance of school food service operations is vital for student learning and public health. This study explored the use of privatization of this function in a case study of a single public school district in Florida. The general literature on government contracting has found that its primary purpose is to save money and improve public services. It can be inferred from the findings of this exploratory study that the district has turned a negative fiscal situation in relation to the food services around, by contracting out. This appears to be motivated by the need to release the financial and operational burden of managing a school food service. The reduction in the burden related to operating peripheral non-instructional services, such as food services, has been proffered as a basic motivation in the past (Belfield and Levin, 2002; O'Toole and Meier, 2004). The field interview data suggested that a significant contributing factor to the financial turnaround of the school district was the relinquishment of HR-related financial responsibilities, such as salaries and fringe benefits.

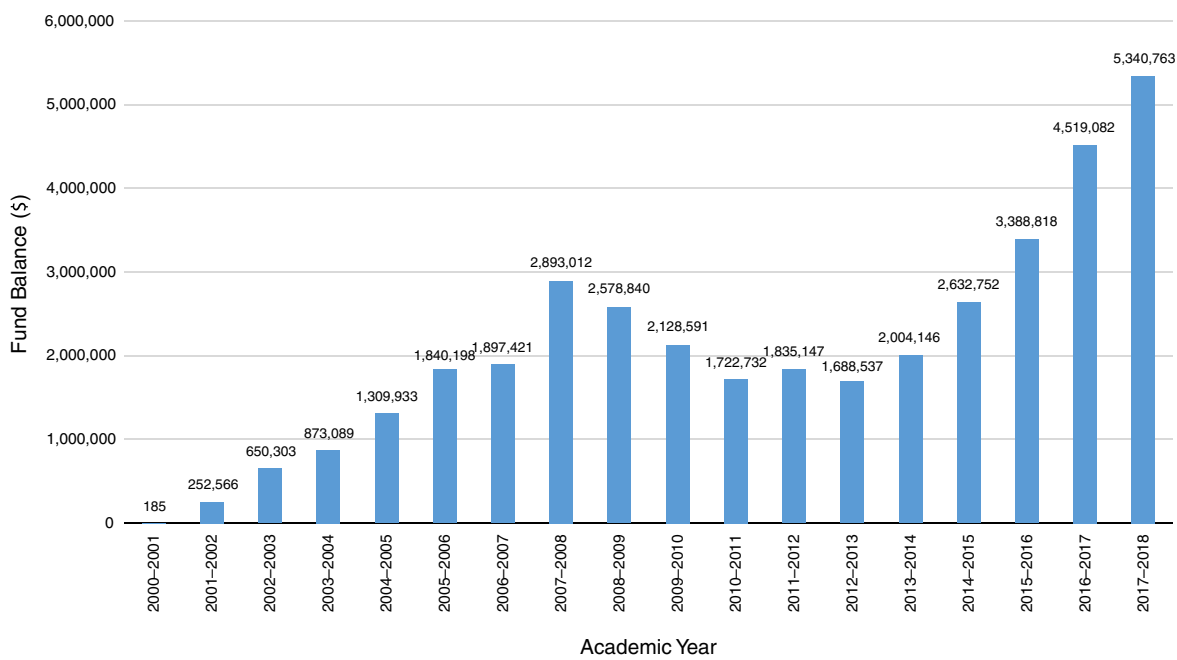

Contracting school meals

Figure 1.

Fund balance of school district special revenue fund (food service) 


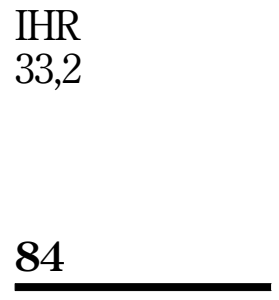

Figure 2 .

Total revenue of school district special revenue fund (food service)

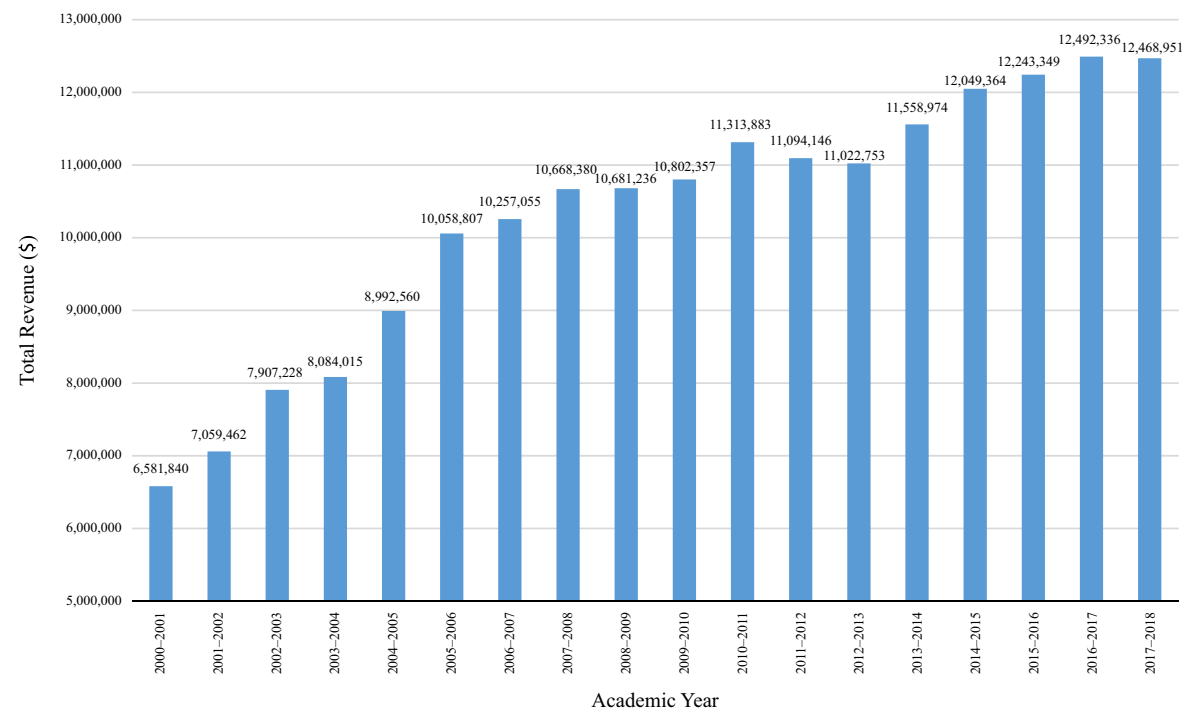

In fact, labor costs and fringe benefits have been found to account for 45 percent of the reported costs for the delivery of reimbursable meals in schools, more than any other factors (US Department of Agriculture, 2008).

The field interview data were supported by the analysis of public documents. The considerable increase in FTE enrollment over this period resulted in a subsequent increase in demand for school food services. The increase in the demand of these services may result in the requirement to contract out as the demand exceeded that ability of the district to provide the service as a required cost and quality (Savas, 2000). The reduction in the burden related to operating peripheral non-instructional services such as food services has been proffered as a basic motivation in the past (Belfield and Levin, 2002; O'Toole and Meier, 2004). Thus, while contracting out for specific services can be related to cost savings, it is also related to effective service delivery and performance (Savas, 2000).

The positive trend in fiscal reports indicate that the contracting out of the school food services may have significantly increased the total revenue generated by school food services. These findings appear to provide evidence for the justification of the main motivation to contract out for the fiscal purposes, where financial resources were freed up to be used for the core service of education. However, these findings are not consistent with O'Toole and Meier (2004). They found that contracting out in public schools in Texas did not release more financial resources to be devoted to the educational delivery. Instead, it reduced the financial support for education and decreased the quality of the service provided.

A major role in maintaining cost savings and a high level of service quality appeared to be the fact that district administration retained ultimate control of the school food services and had the ability to renegotiate the contract on a regular basis. Additionally, it is especially important for school districts to possess the culinary skills that allow for the production of such food items that the students are encouraged to participate in federal school meal programs. It has been stated that there has been a significant decline in students' participation in the NSLP due to the decrease in students' acceptance of meals since the introduction of the new nutrition standards in 2012 (School Nutrition Association, 2015). In fact, the importance of creating incentives to reduce costs through competition among private vendors has been emphasized by scholars (Kassel, 2010; Curry, 2010). 
Limitations and future research

There are limitations to this research. First, our study is based on a single school district. It has a key weakness in generalizing findings to other school districts. Second, our results are based on a small number of interviewees, which might reflect the individuals' subjective perceptions. To overcome these limitations, future studies are suggested to design a nationwide survey to investigate the motivations and impacts of contracting out school food services. In addition, an in-depth comparison between privatized and non-privatized school food services can be valuable.
Contracting school meals

\section{References}

Alonso, J.M., Clifton, J. and Díaz-Fuentes, D. (2015), "Did new public management matter? An empirical analysis of the outsourcing and decentralization effects on public sector size", Public Management Review, Vol. 17 No. 5, pp. 643-660.

Alspaugh, J.W. (1996), "The effects of geographic and management factors on the cost of pupil transportation", Journal of Education Finance, Vol. 22 No. 3, pp. 180-194.

Bekken, J.T., Longva, F., Fearnley, N. and Osland, O. (2006), "Norwegian experiences with tendered bus services", European Transport, Vol. 33, pp. 29-40.

Bel, G., Fageda, X. and Warner, M.E. (2010), "Is private production of public services cheaper than public production? A meta-regression analysis of solid waste and water services", Journal of Policy Analysis and Management, Vol. 29 No. 3, pp. 553-577.

Belfield, C.R. and Levin, H.M. (2002), Education Privatization: Causes, Consequences and Planning Implications, International Institute for Educational Planning, UNESCO, New York, NY.

Bhatti, Y., Olsen, A.L. and Pedersen, L.H. (2009), "The effects of administrative professionals on contracting out", Governance, Vol. 22 No. 1, pp. 121-137.

Blom-Hansen, J. (2003), "Is private delivery of public services really cheaper? Evidence from public road maintenance in Denmark", Public Choice, Vol. 115 No. 3, pp. 419-438.

Boyne, G.A. (1998), "Bureaucratic theory meets reality: public choice and service contracting in US local government”, Public Administration Review, Vol. 58 No. 6, pp. 474-484.

Braun, V. and Clarke, V. (2006), "Using thematic analysis in psychology", Qualitative Research in Psychology, Vol. 3 No. 2, pp. 77-101.

Brooks, R.C. (1995), "An analysis of residential sanitation collection pricing under alternative delivery arrangements", Journal of Public Budgeting, Accounting \& Financial Management, Vol. 7 No. 4, pp. 493-514.

Burch, P. (2006), "The new educational privatization: educational contracting and high stakes accountability", Teachers College Record, Vol. 108 No. 12, pp. 2582-2610.

Byker Shanks, C., Banna, J. and Serrano, E.L. (2017), "Food waste in the national school lunch program 1978-2015: a systematic review", Journal of the Academy of Nutrition and Dietetics, Vol. 117 No. 11, pp. 1782-1807.

Callan, S.J. and Thomas, J.M. (2001), "Economies of scale and scope: a cost analysis of municipal solid waste services", Land Economics, Vol. 77 No. 4, pp. 548-560.

Creswell, J. (2007), Qualitative Inquiry and Research Design: Choosing Among Five Approaches, 2nd ed., Sage, Thousand Oaks, CA.

Curry, W. (2010), Government Contracting: Promises and Perils, CRC Press, Boca Raton, FL.

Domberger, S. and Jensen, P. (1997), "Contracting out by the public sector: theory, evidence, prospects", Oxford Review of Economic Policy, Vol. 13 No. 4, pp. 67-78.

Ferris, J.M. (1986), "The decision to contract out: an empirical analysis", Urban Affairs Review, Vol. 22 No. 2, pp. 289-311.

Florida Legislator (2017), "Office of economic and demographic research", available at: http://edr.statefl.us (accessed January 3, 2019). 
IHR

33,2

Florida School Food Nutrition Association (2015), "Florida fact sheet regarding school breakfast and lunch participation", available at: www.floridaschoolnutrition.org/4DCGI $/ \mathrm{cms} /$ review.html? Action=CMS_Document\&DocID=117\&MenuKey=123S (accessed February 6, 2016).

Glickman, T.S., Holm, J., Keating, D., Pannait, C. and White, S.C. (2007), "Outsourcing on American campuses: national developments and the food service experience at GWU", International Journal of Educational Management, Vol. 21 No. 5, pp. 440-452.

Gupta, A., Herath, S.K. and Mikouiza, N.C. (2005), "Outsourcing in higher education: an empirical examination”, International Journal of Educational Management, Vol. 19 No. 4, pp. 396-411.

Harding, R.W. (1990), "Contracting out the bussing of school children: an industrial organization approach", unpublished doctoral dissertation, University of California, Los Angeles, CA.

Hart, O., Shleifer, A.S. and Vishny, R.W. (1997), "The proper scope of government: theory and application to prisons", The Quarterly Journal of Economics, Vol. 112 No. 4, pp. 1127-1161.

Hodge, G.A. (2000), Privatization: An International Review of Performance, Westview Press, Boulder, CO.

Hohman, J.M. and Cammenga, J. (2017), Michigan School Privatization Survey 2017, Mackinac Center, Midland, MI.

Hohman, J.M. and Kollmeyer, J.M. (2011), Michigan School Privatization Survey 2011, Mackinac Center, Midland, MI.

Hohman, J.M. and Woodman, Z. (2015), School Support Service Privatization: A Five-State Survey, Mackinac Center, Midland, MI.

Houlberg, K. and Petersen, O.H. (2015), Økonomiske effekter af konkurrenceudscettelse på det kommunale vejområde (Economic Effects of Outsourcing of Road Construction), Roskilde University, Roskilde.

Hutchcraft, C. and Hume, S. (2000), “Union watch”, Restaurants \& Institutions, Vol. 110 No. 11, pp. 46-62.

Kassel, D.S. (2010), Managing Public Sector Projects, CRC Press, Boca Raton, FL.

King, P. (1997), "Contractors give 'the old college try' in battle for university food dollars", Nation's Restaurant News, Vol. 31 No. 27, pp. 57-64.

LaFaive, M.D. (2007), A School Privatization Primer for Michigan School Officials, Media and Residents, Mackinac Center, Midland, MI.

Lawn, J. (2003), "New demands drive campus dining programs”, Food Management, Vol. 38 No. 6, pp. 8-10.

LeBruto, S.M. and Farsad, B. (1993), "Contracted school food service: advantages, disadvantages, and political concerns", Hospitality Review, Vol. 11 No. 1, pp. 57-67.

Levin, H.M. and McEwan, P.J. (2002), Cost-Effectiveness and Educational Policy, Eye on Education, Larchmont, NJ.

Levine, S. (2010), School Lunch Politics: The Surprising History of America's Favorite Welfare Program, Princeton University Press, Princeton, NJ.

McConnell, D. (1999), "Self-op or contract”, Food Management, Vol. 34 No. 4, pp. 11-18.

McGuire, R.A. and Van Cott, N.T. (1984), "Public versus private economic activity: a new look at school bus transportation”, Public Choice, Vol. 43 No. 1, pp. 25-43.

Mathis, W.J. and Jimerson, L. (2008), "A guide to contracting out school support services: good for the school? Good for the community?", Education and the Public Interest \& Education Policy Research Unit, East Lansing, MI, available at: http://greatlakescenter.org/docs/Policy_Briefs/ Mathis_ContractingOut.pdf

Nestle, M. (2002), Food Politics, University of California Press, Berkeley, CA.

Nicholson-Crotty, S. (2004), "The politics and administration of privatization: contracting out for corrections management in the United States", The Policy Studies Journal, Vol. 32 No. 1, pp. 41-57.

Ohlsson, H. (2003), "Ownership and production costs: choosing between public production and contractingout in the case of Swedish refuse collection", Fiscal Studies, Vol. 24 No. 4, pp. 451-476.

O’Toole, L.J. and Meier, K.J. (2004), "Parkinson's law and the new public management? Contracting determinants and service-quality consequences in public education”, Public Administration Review, Vol. 64 No. 3, pp. 342-352. 
Petersen, O.H. and Hjelmar, U. (2013), "Marketization of welfare services in Scandinavia: a review of Swedish and Danish experiences", Scandinavian Journal of Public Administration, Vol. 17 No. 4, pp. 3-20.

Petersen, O.H., Hjelmar, U. and Vrangbaek, K. (2018), "Is contracting out of public services still the great panacea? A systematic review of studies on economic and quality effects from 2000 to 2014", Social Policy \& Administration, Vol. 52 No. 1, pp. 130-157.

Rho, E. (2013), "Contracting revisited: determinants and consequences of contracting out for public education services", Public Administration Review, Vol. 73 No. 2, pp. 327-337.

Rostgaard, T. and Szebehely, M. (2012), "Changing policies, changing patterns of care: Danish and Swedish home care at the crossroads", European Journal of Ageing, Vol. 9 No. 2, pp. 101-109.

Savas, E.S. (1977), "An empirical study of competition in municipal service delivery", Public Administration Review, Vol. 37 No. 6, pp. 717-724.

Savas, E.S. (2000), Privatization and Public-Private Partnership, Chatham House, New York, NY.

Savas, E.S. (2005), Privatization in the City: Successes, Failures, Lessons, CQ Press, Washington, DC.

School Nutrition Association (2015), "Costs of nutrition standards threaten school meal programs (press release)", available at: http://schoolnutrition.org/PressReleases/CostsofNutrition StandardsThreatenSchoolMealPrograms/ (accessed April 8, 2016).

Spann, R.M. (1977), "Public versus private production of governmental services", in Borcherding, T.E. (Ed.), Budgets and Bureaucrats: The Sources of Governmental Growth, Duke University Press, Durham, NC, pp. 71-89.

Stolt, R., Blomqvist, P. and Winblad, U. (2011), "Privatization of social services: quality differences in Swedish elderly care”, Social Science \& Medicine, Vol. 72 No. 4, pp. 560-567.

US Census Bureau (2018), “Quick facts santa rosa county, Florida”, available at: www.census.gov/ quickfacts/santarosacountyflorida (accessed January 5, 2019).

US Department of Agriculture (2008), "School lunch and breakfast cost study-ii healthy, hunger-free kids act of 2010 (Report No. cn-08/MCII)", Government Printing Office, Washington, DC.

US Department of Agriculture (2013), National School Lunch Program: Direct Certification Continuous Improvement Plans Required by Healthy, Hunger-Free Kids Act of 2010 (Federal Register 78 (36.), US Government Printing Office, Washington, DC.

US Department of Agriculture (2015a), "USDA unveils historic improvements to meals served in America's schools (press release)", available at: www.fns.usda.gov/pressrelease/002312 (accessed March 16, 2016).

US Department of Agriculture (2015b), "National school lunch program fact sheet, 2015", available at: www.fns.usda.gov/sites/default/files/NSLPFactSheet.pdf (accessed February 21, 2016).

US Government Accountability Office (2011), "Acquisition management: GAO high risk and other major government challenges", available at: www.gao.gov/highrisk/challenges acquisition_ management/home_acquisition_management.php (accessed December 31, 2018).

VanderSchee, C. (2005), "The privatization of food services in schools: undermining children's health, social equity, and democratic education", in Boyles, D.R. (Ed.), Schools or Markets? Commercialism, Privatization, and School-Business Partnerships, Lawrence Erlbaum Associates, Mahwah, NJ, pp. 1-30.

\section{Further reading}

Achterberg, C. and Arendt, S. (2008), "The philosophy, role, and methods of qualitative inquiry in research", in Monsen, E.R. and Van Horn, L. (Eds), Research: Successful Approaches, 3rd ed., American Dietetic Association, Chicago, IL, pp. 65-78.

Arendt, S., Roberts, K., Stohbehn, C., Ellis, J., Paez, P. and Meyer, J. (2012), "Use of qualitative research in foodservice organizations", International Journal of Contemporary Hospitality Management, Vol. 24 No. 6, pp. 820-837. 
IHR

33,2

Binder, P., Kessler, A., Mair, M. and Stummer, K. (2013), "Organizational innovativeness and its results: a qualitative analysis of SME hotels in Vienna", Journal of Hospitality \& Tourism Research, Vol. 40 No. 3, pp. 339-363.

Crawford, A. (2013), "Hospitality operators' understanding of service: a qualitative approach", International Journal of Contemporary Hospitality Management, Vol. 25 No. 1, pp. 65-81.

Curry, L., Nembhard, I. and Bradley, E. (2009), "Qualitative and mixed methods provide unique contributions to outcomes research", Circulation, Vol. 19 No. 10, pp. 1442-1152.

Hux, A.R. and Nichols, J.R. (2016), "The financial and political impacts of labor-outsourcing in rural school districts", Education, Vol. 136 No. 3, pp. 275-282.

Kwortnik, R. (2003), "Clarifying 'fuzzy' hospitality-management problems with depth interview and qualitative analysis", Cornell Hotel and Restaurant Administration Quarterly, Vol. 44 No. 2, pp. 117-129.

Lo, C.Y., Liu, B.C., Hou, C.I. and Kao, Y.T. (2015), "Selection model for school lunch suppliers of junior high schools", International Journal of Research in Business Studies and Management, Vol. 2 No. 4, pp. 72-77.

Poria, Y., Reichel, A. and Brandt, Y. (2010), "The flight experiences of people with disabilities: an exploratory study", Journal of Travel Research, Vol. 49 No. 2, pp. 216-227.

Poria, Y., Reichel, A. and Brandt, Y. (2011), "Dimensions of hotel experience of people with disabilities: an exploratory study", International Journal of Contemporary Hospitality Management, Vol. 23 No. 5, pp. 571-591.

Riley, R. and Love, L. (2000), "The state of qualitative tourism research”, Annals of Tourism Research, Vol. 27 No. 1, pp. 164-187.

Savas, E.S. (1999), Privatization and Public-Private Partnerships, Sage, New York, NY.

Tashakkori, A. and Teddlie, C. (2002), Handbook of Mixed Methods in Social and Behavioral Research, Sage, Thousand Oaks, CA.

US Department of Agriculture (2015c), "USDA announces grants for childhood obesity prevention programs (press release)", available at: www.usda.gov/wps/portal/usda/usdahome?contentidonly= true\&contentid=2015/03/0075.xml (accessed February 21, 2016).

US GAO (2008), "Meal counting and claiming by food service management companies in the school meal programs", available at: www.gao.gov/products/GAO-09-156R (accessed December 5, 2018).

Walsh, K. (2003), "Qualitative research: advancing the science and practice of hospitality", Cornell Hotel and Restaurant Administration Quarterly, Vol. 44 No. 2, pp. 66-74. 


\section{Appendix. Interview Questions for the Privatized School Food Services District}

Name of Interviewee:

Date:

\section{Part I. Background Questions}

What is your current position?

How long have you been in this position?

$>$ What is your current job responsibility relative to school food services?

$>$ What are the federally assisted school meal/nutrition programs (e.g., the National School Lunch Program (NSLP), the School Breakfast Program (SBP), and the Special Milk Program for Children (SMP)) currently being operated in your district?

$>$ How many students participate in your district's school meal/nutrition programs?

\section{Part II. The Decision to Privatize School Food Services}

How long have food services been privatized in this school district?

$>$ What are the current contracted food service management companies?

$>$ What would you say were the primary reasons or goals for privatizing school food services?

$>$ In your opinion, what are the perceived pros and cons regarding privatized school food services?

$>$ Were there any objections to the privatization of the district's school food services? If so, how did your district overcome the opposition?

\section{Part III. Perception about the Financial Impact of School Food Services Privatization}

$>$ Do you believe that privatized school food services provide financially benefits or disadvantages your district?

$>$ What are the major financial benefits or disadvantages for your school district regarding the privatization of school food services? (e.g. meal cost savings/losses, increased/decreased selection of varying food items, more/less efficient and professional food service preparation and operation?)

$>$ How does the privatization of school food services generate these financial benefits or disadvantages for your district?

$>$ What are your school district's current average meal costs per student for school breakfast and lunch?

$>$ Do you believe that the privatization of school food services has allowed your school district to remain within the operating budget? To what extent?

\section{Part IV. Perception about the Nutritional Benefits of School Food Services Privatization}

How do you feel the involvement of a private food service management company has impacted your district's ability to offer healthy food options? (e.g. fresh fruit and vegetable, low fat or non-fat dairy products, whole grain foods)?

$>$ How do you feel that the menu options offered by the private food service management company have impacted your district's ability to educate the students on eating healthier food choices?
Contracting school meals 
$>$ How do you feel the involvement of a private food service management company has impacted your district's ability to meet federal nutritional quality requirements and standards for school meals offered?

$>$ Have there been any changes in student behavior since the implementation of privatized food service (i.e. increased disciplinary actions, enrollment in extracurricular activities, etc.)?

$>$ Have there been any changes in overall student grade averages since the implementation of privatized food service?

\section{Part V. Privatized School Food Services Regulation Compliance}

What nutritional standards and regulations are you required to comply with?

$>$ What type of infrastructure do you have in place to ensure regulation compliance?

$>$ What long-term data/tracking is being done?

$>$ What are the ramifications if these standards are not met?

Conclusion:

Is there anything else about privatized school food services you would like to share?

\section{Corresponding author}

Mark Traynor can be contacted at: mtraynor@fiu.edu

For instructions on how to order reprints of this article, please visit our website: 